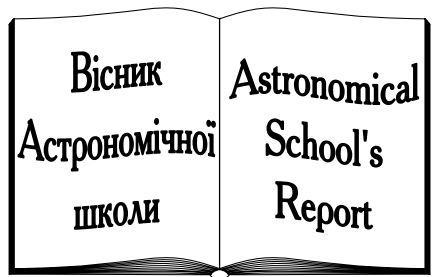

ISSN 1607-2855

Том $7 \bullet$ •№ $2 \bullet 2011 \quad$ C. $145-149$

UDC 523.6

\title{
Meteorites as a natural detectors of very heavy galactic cosmic ray nuclei: some aspects of the experimental track studies
}

\author{
A.B. Aleksandrov ${ }^{1}$, A.V. Bagulya ${ }^{1}$, M.S. Vladimirov ${ }^{1}$, L.A. Goncharova ${ }^{1}$, A.I. Ivliev ${ }^{2}$, \\ G.V. Kalinina $^{2}$, L.L. Kashkarov ${ }^{2}$, N.S. Konovalova ${ }^{1}$, N.M. Okateva ${ }^{1}$, N.G. Polukhina ${ }^{1}$, \\ A.S. Roussetski ${ }^{1}$, N.I.Starkov ${ }^{1}$, V.A. Tsarev ${ }^{1}$ \\ ${ }^{1}$ Lebedev Physical Institute, Russian Academy of Sciences, Moscow \\ ${ }^{2}$ Vernadsky Institute of Geochemistry and Analytical Chemistry, Russian Academy of Sciences, Moscow
}

In this work performed in frame to OLIMPIYA project [5] there are presented new results of measurement of fluxes and of the spectra of superheavy nuclei composing cosmic rays. The method of detection and analysis of nucleus tracks found in the olivine crystals of meteorites was used. The experiment is based on the combined method including the multistage meteorite etching and nucleus track registration and measurement on completely automated PAVICOM setup [5]. The track parameters such as diameter, length and the etching velocity are investigated. On the first stage of the experiment there was held the calibration procedure for nuclei charge identification using the accelerated nuclei $X e$ and $U$. The etching length of nuclei $(26<Z<92)$ was simulated on SRIM2006 and GEANT4 tools. Up to date, the data bank includes near 1000 registered long path tracks $(L \geqslant 30 \mu \mathrm{m})$ with their parameters registered in 27 olivine crystals of 1-2 $\mathrm{mm}$. These data give estimations for the relative values of the flux intensities of the galactic cosmic ray nuclei with $23 \leqslant Z \leqslant 28, Z \geqslant 30, Z \geqslant 40, Z \geqslant 50, Z \geqslant 60$ and $Z \geqslant 70$.

МЕТЕОРИТЫ КАК ПРИРОДНЫЕ ДЕТЕКТОРЫ ОЧЕНЬ ТЯЖЕЛЫХ ЯДЕР ГАЛАКТИЧЕСКИХ КОСМИЧЕСКИХ ЛУЧЕЙ: НЕКОТОРЫЕ АСПЕКТЫ ЭКСПЕРИМЕНТАЛЬНОГО ИЗУЧЕНИЯ ТРЕКОВ, АлекСандров А.Б., Багуля А.В., Владимиров М.С., Гончарова Л.А., Ивлиев А.И., Калинина Г.В., Кашкаров Л.Л., Коновалова Н.С., Окатьева Н.М., Полухина Н.Г., Русеикий А.С., Старков Н.И., Царев В.А. - В работе, проводимой по проекту ОЛИМПИЯ [5], представлень результаты исследования зарядового состава и интенсивности потока ядер VVH-группь космических лучей, основанные на измерении и анализе параметров треков, наблюдаемых в кристаллах оливина из палласита Марьялахти. Нсследования основаны на: (а) Применении модифииированной методики многоступенчатого последовательного травления, регистрации и высокоточного измерения на Полностью Автоматизированном Измерительном Комплексе ПАВИКОМ [5] динамических (скорость травления) и геометрических (диаметр и длина) параметров треков - химически травимых следов торможения ядер в кристаллах оливина; (б) Ндентификации заряда ядер по данным калибровочных экспериментов с ускоренными ядрами Хе и U, а также теоретически рассчитанной при помощи программ SRIM2006 и GEANT4 химически травимой длине треков для ядер с зарядом $26<Z<92$. Анализ параметров около 1000 длиннопробежных $(L \geqslant 30 \mu т)$ треков, зарегистрированных в изученных 27-ми кристаллах оливина размером $\sim(1-2)$ мм, позволил оценить величины интенсивности потока ядер космических лучей с зарядом $23 \leqslant Z \leqslant 28, Z \geqslant 30, Z \geqslant 40, Z \geqslant 50, Z \geqslant 60$ и $Z \geqslant 70$.

МЕТЕОРИТИ ЯК ПРИРОДНІ ДЕТЕКТОРИ ДУЖЕ ВАЖКИХ ЯДЕР ГАЛАКТИЧНИХ КОСМІЧНИХ ПРОМЕНІВ: ДЕЯКІ АСПЕКТИ ЕКСПЕРИМЕНТАЛЬНОГО ВИВЧЕННЯ ТРЕКІВ, Александров А.Б., Багуля А.В., Владимиров М.С., Гончарова Л.А., Івлієв А.І., Калініна Г.В., Кашкаров Л.Л., Коновалова Н.С., Окатьева Н.М., Полухіна Н.Г., Русещький А.С., Старков Н.І., Царьов В.А. - У роботі, що проводиться за проектом ОЛІМПІЯ [5], представлені результати дослідження зарядового складу і інтенсивності потоку ядер VVН-групи космічних променів, засновані на вимірюванні та аналізі параметрів треків, які спостерігаються в кристалах олівіну з палласіта Марьялахті. Дослідження засновані на: (а) Застосуванні модифікованої методики багатоступінчастого послідовного травлення, реєстраиії і високоточного вимірювання на повністю автоматизованому вимірювальному комплексі ПАВИКОМ [5] динамічних (ивидкість травлення) і геометричних (діаметр і довжина) параметрів треків - хімічно травімих слідів гальмування ядер в кристалах олівіну; (б) Ідентифікаціі заряду ядер за даними калібрувальних експериментів з прискореними ядрами Хе $i$, a також теоретично розрахованої за допомогою програм SRIM2006 і GEANT4 хімічно травімой довжині треків для ядер із зарядом $26<Z<92$. Аналіз параметрів близько 1000 довгопробінних $(L \geqslant 30 \mu \mathrm{m})$ треків, зареєстрованих у вивчених 27-ми кристалах олівіну розміром $(1-2)$ мм, дозволив оцінити величини інтенсивності потоку ядер космічних променів з зарядом $23 \leqslant Z \leqslant 28, Z \geqslant 30, Z \geqslant 40, Z \geqslant 50, Z \geqslant 60 \mathrm{ma} Z \geqslant 70$.

Ключевые слова: метеориты; галактические космические лучи; тяжелые ядра.

Key words: meteorites; galactic cosmic rays; heavy nuclei.

\section{INTRODUCTION}

Detection of heavy, very heavy and super heavy nuclei in galactic cosmic rays and search for transuranium nuclei with charges $Z \geqslant 110$ are among the most important and topical problems of modern nuclear physics and astrophysics [1]. The issue of the existence of super heavy nuclei is of the utmost importance for gaining an insight into the nature of nuclear matter. First of all, of interest is the check of the predicted [2] considerable enhancement of the nuclear stability near the magic numbers $Z=114$, which could result in 
the existence of "stability islands" for super heavy nuclei in this region. The very first corroboration of this prediction was recently obtained at the Joint Institute Nuclear Research, Dubna in the accelerator experiments, where the 114-th and 116-th elements were discovered [3].

In common with previous studies with the meteoritic olivine as the natural heavy nuclei track detector [4], the "OLIMPIYA" project [5] is based on the harnessing of the solid-state track detector technique, where radiation damages produced by penetrating particles in the silicate mineral olivine are used to direct detection of these particles. In the search for ancient tracks use is made of the ability of silicate crystals from meteorites to register and preserve over a long period of time $\left(>10^{8}\right.$ years) tracks of nuclei with $Z \geqslant 23$ [6]. Thus, the employment of meteorites provides tremendous advantage of this method over the methods based on the use of various satellite-borne and balloon-borne detectors.

\section{SEARCHED MATERIALS AND METHOD}

In common, measuring of the dynamical (etching rate of the track length) and geometry (etchable track canal length and diameters) parameters both for the fossil and artificially produced by the accelerated nuclei give possibility to identify charge of nuclei. In this paper some methodological aspects of the fossil tracks investigation in the meteoritic olivine crystals are presented.

In our investigation the olivine crystals, extracted from the pallasite Marjalahti, were used. The age of this meteorite as an individual cosmic objects and, consequently, the time of their exposition in the cosmic ray flux, were determined at $\sim 175 \cdot 10^{6}$ years. According to our estimates, during this time up to $\sim 10^{3}$ tracks of nuclei with $Z \geqslant 90$ could be produced in the total volume of the searched crystals near of $1 \mathrm{~cm}^{3}$, that were sited at $\leqslant 5 \mathrm{~cm}$ beneath the pre-atmospheric meteorite surface.

\section{SCANNING MEASUREMENTS AND THE TRACK DATA PROCESSING}

Based in our investigation on the "OLIMPIYA" project [5], the problem of scanning, measurements and processing particle-track data is solved through the use of the modern high-performance completely automated measuring complex PAVICOM [7].

The PAVICOM program provides track scanning over three coordinates, gives pointing for the track found, and measures its length and shape with an accuracy of near $1 \mu \mathrm{m}$. The image joining is also performed if the track length exceeds the size of the single field of view of the microscope. At the track intersection, the program will identify such events and process each track separately. In Fig. 1. PAVICOM microphotographs of the one long track, registered at consistent four depths in the olivine crystal of the Marjalahti pallasite after etching during of 48 hours are presented.

On the olivine etching, the zones of dislocations and other defects can look like nuclear tracks; therefore, the program is adapted for analyzing the track from its origin to the vertex in order to distinguished it

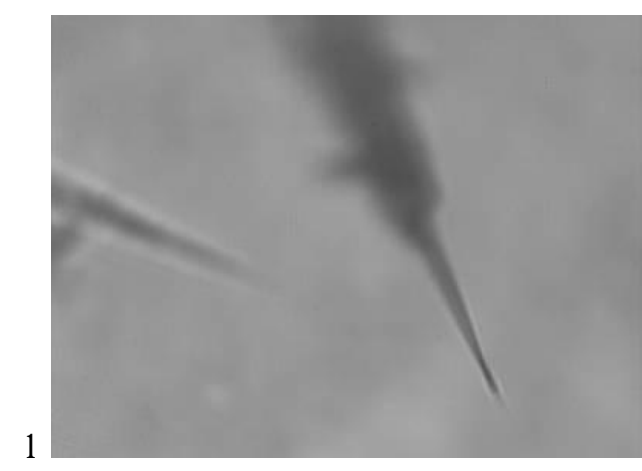

3

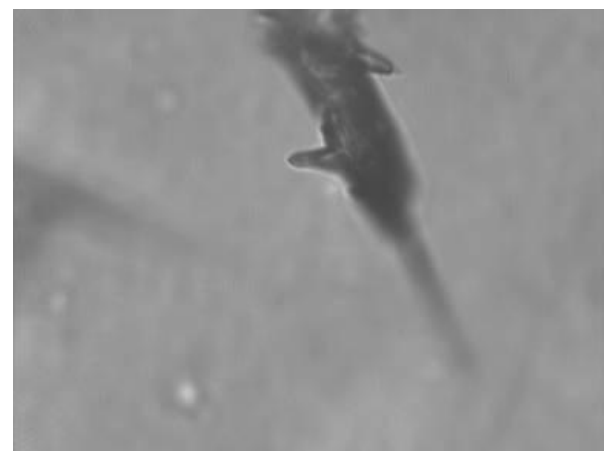

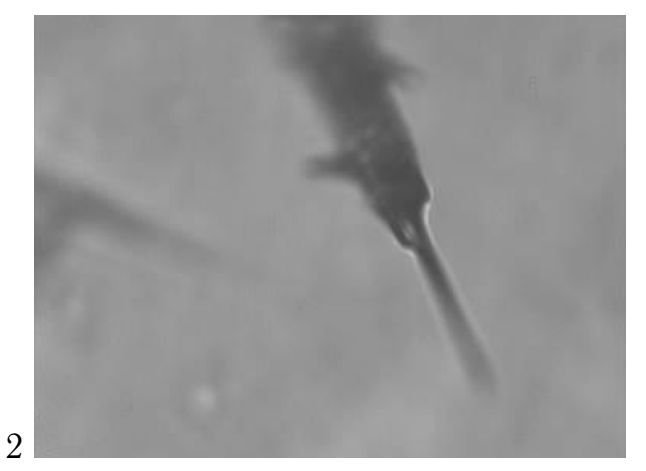

2

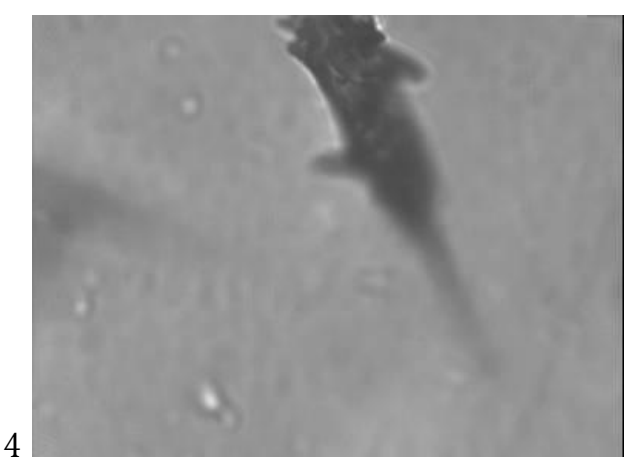

Fig. 1. PAVICOM microphotographs of the one long track, registered at consistent (1-4) depths up to $\sim 50 \mu \mathrm{m}$ in the internal olivine crystal polished surface of the Marjalahti pallasite after etching during of 48 hours in the standard solution and conditions. Each picture area is $\sim 100 \times 120 \mu \mathrm{m}$. 
from the etched defects. The novelty of the proposed approach is essentially associated with the mean of tackling these difficulties. This became feasible owing to the progress achieved in the last few years in the production of a precision technique and advent of optical tables with high precision of the movement on computer commands, widespread use of modern charge-coupled devices for detection and digitalization of optical images, and high potentialities of modern computers.

Taken together these achievements make possible complete automation of the scanning and measurements and speed up the processing by about three orders of magnitude as compared with what the so-called semiautomatic devices can do.

\section{TRACK PARAMETERS DETERMINATION}

Particle charge and momentum determination from the track geometrical parameters requires the measurement of the particle ionization energy loss on the track final stopping area. The fact that the observable chemically etched track is formed only in area where ionization energy loss $(d E / d x)_{e}$ exceeds some critical value $(d E / d x)_{c}[8]$ is of vital importance for the method. The value of $(d E / d x)_{c}$ is an individual characteristic of track detector material [9]. For olivine crystals, in [10] there was obtained $(d E / d x)_{c} \sim 18\left(\mathrm{GeV} / \mathrm{g} \cdot \mathrm{cm}^{-2}\right)$. It brings, in particular, to the limit of possible charge $(Z \geqslant 26)$ of a particle that could be registered by the presented method.

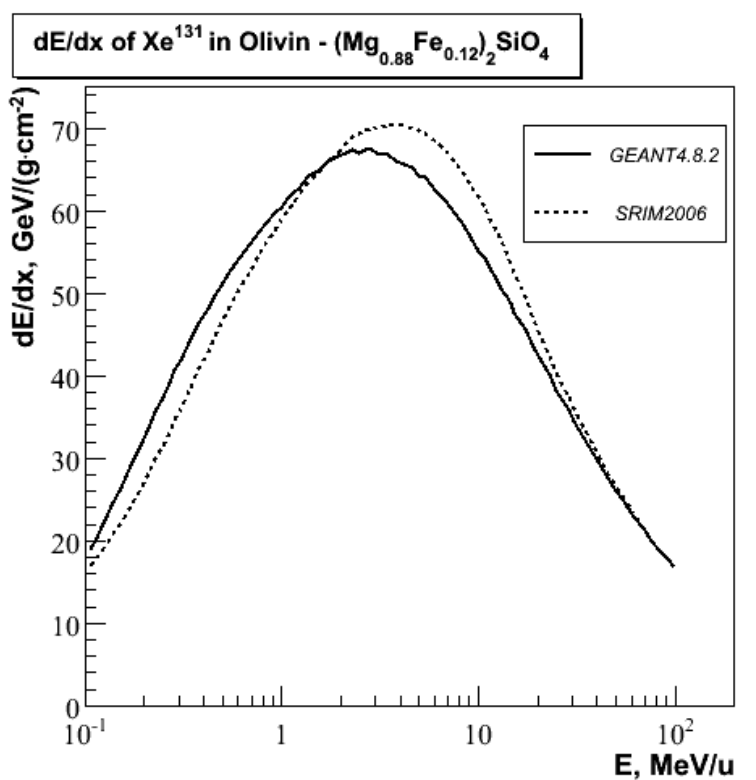

(a)

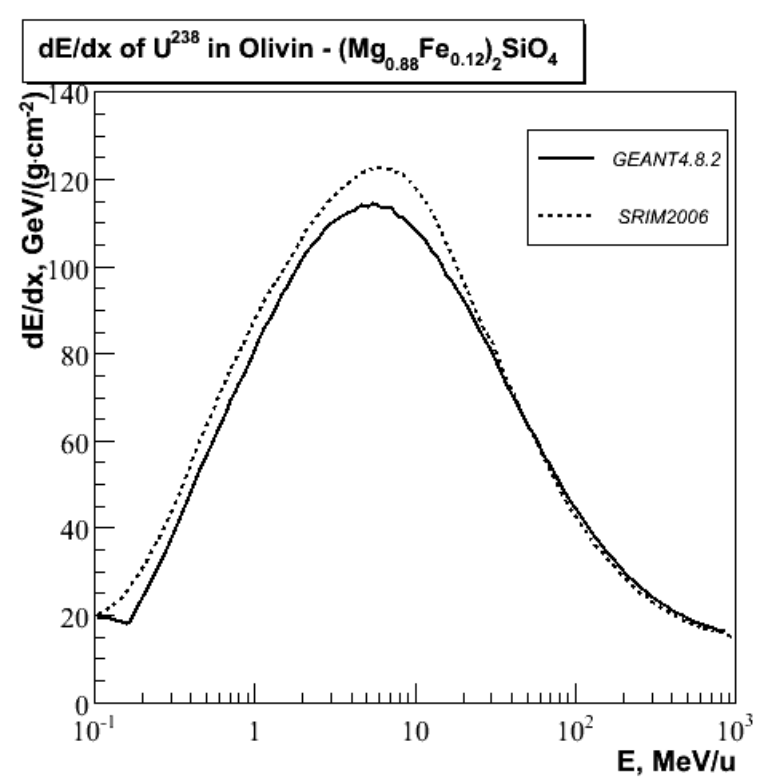

(b)

Fig. 2. Ionization energy loss for ions $\mathrm{Xe}^{131}$ and $\mathrm{U}^{238}$ as a function of their energy while slowing-down in olivine with composition $\left(\mathrm{Mg}_{0.88} \mathrm{Fe}_{0.12}\right)_{2} \mathrm{SiO}_{4}$

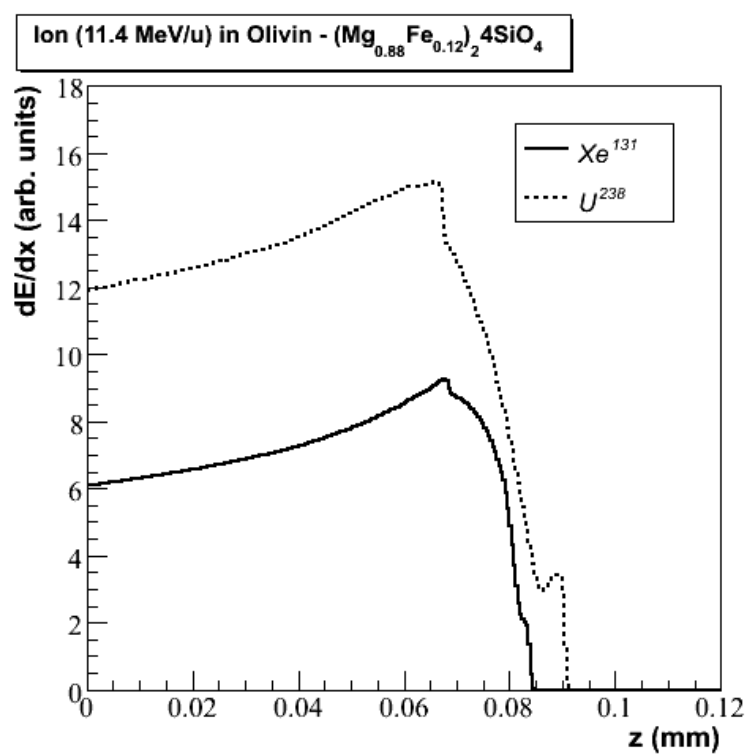

Fig. 3. Profile of energy loss for $\mathrm{Xe}^{131}$ and $\mathrm{U}^{238}$ beams passing through olivine with composition $\left(\mathrm{Mg}_{0.88} \mathrm{Fe}_{0.12}\right)_{2} \mathrm{SiO}_{4}$ 
Table 1. Calculation of the chemically etched track length for the very heavy nuclei in the olivine of composition $\left(\mathrm{Mg}_{0.88} \mathrm{Fe}_{0.12}\right)_{2} \mathrm{SiO}_{4}$, corresponding to the Marjalahti pallasite

\begin{tabular}{|c|c|c|c|c|}
\hline Nuclei & $E_{\max } \div E_{\min }{ }^{(*)}, M e V$ & $R_{\max } \div R_{\min }{ }^{(* *)}, \mu \mathrm{m}$ & $L_{\Sigma}{ }^{(* * *)}, \mu \mathrm{m}$ & $L_{\mathrm{BASE}}{ }^{(* * * *)}, \mu \mathrm{m}$ \\
\hline Fe (26) & $610 \div 10.5$ & $80 \div 3.1$ & 77 & $15 \pm 1$ \\
Zn (30) & $1050 \div 10.5$ & $130 \div 3.1$ & 127 & 25 \\
$\mathrm{Kr}(36)$ & $2400 \div 13.4$ & $275 \div 3.8$ & 271 & 55 \\
$\mathrm{Ag}(47)$ & $6400 \div 14.2$ & $700 \div 3.8$ & 696 & 140 \\
Xe (54) & $11800 \div 28$ & $1260 \div 3.4$ & 1257 & 250 \\
\hline
\end{tabular}

${ }^{(*)}\left(E_{\max } \div E_{\min }\right)-$ interval, corresponding to $(d E / d x)_{\mathrm{CR}} \sim 18 \mathrm{MeV} / \mathrm{mg} \mathrm{cm}^{-2}$;

(**) - Path-range of the nuclei, corresponding to energy-interval of $\left(E_{\max } \div E_{\min }\right)$;

${ }^{(* * *)} L_{\Sigma}-$ the total chemically etched track length;

${ }^{(* * * *)} L_{\text {BASE }}$ - chemically etched track length of the base track zone.

Table 2. Relative flux value of the galactic cosmic ray nuclei with the charge $Z$ in interval of 56-92, determined by the track analyses of the olivine crystals from the Marjalahti pallasite

\begin{tabular}{|c|c|c|c|c|}
\hline Charge group & $N_{Z}^{(*)}$ & $L, \mu \mathrm{m}^{(* *)}$ & Track density, $\mathrm{cm}^{-3}$ & $\begin{array}{c}\text { Relative nuclei } \\
\text { flux value }\end{array}$ \\
\hline $23 \leqslant Z \leqslant 28$ & $\sim 3000$ & $3-14$ & $(1-5) \cdot 10^{9}$ & 1 \\
$56 \leqslant Z \leqslant 59$ & 133 & $100-150$ & $6.0 \cdot 10^{4}$ & $2 \cdot 10^{-5}$ \\
$60 \leqslant Z \leqslant 69$ & 282 & $150-300$ & $1.3 \cdot 10^{5}$ & $4.3 \cdot 10^{-5}$ \\
$70 \leqslant Z \leqslant 79$ & 146 & $300-500$ & $6.6 \cdot 10^{4}$ & $2.2 \cdot 10^{-5}$ \\
$80 \leqslant Z \leqslant 89$ & 8 & $500-700$ & $3.6 \cdot 10^{3}$ & $1.2 \cdot 10^{-6}$ \\
$90 \leqslant Z \leqslant 92$ & 4 & $>800$ & $1.8 \cdot 10^{3}$ & $6 \cdot 10^{-7}$ \\
\hline
\end{tabular}

${ }^{(*)} N_{Z}$ - number of tracks registered in the total volume of $\sim 2.2 \mathrm{~mm}^{3}$ in 27 olivine crystals under investigation;

${ }^{(*)}$ Etchable track length $L$, determined during of (3-4)-multiple 48-hour time interval.

Table 3. Relative flux values of the galactic cosmic ray nuclei of different charge intervals, determined by the track analyses of the olivine crystals from the Marjalahti pallasite by the data of present work and Perelygin et al. [15].

\begin{tabular}{|c|c|c|c|}
\hline $\begin{array}{c}\text { Nuclei charge } \\
\text { group }^{(*)}\end{array}$ & \multicolumn{3}{|c|}{$N_{Z} / N_{23<Z<28}$} \\
\cline { 2 - 4 } & Present work ${ }^{(*)}$ & Perelygin et al. [15] $]^{(* *)}$ & Cameron [16] \\
\hline $57<Z<62$ & $3.1 \cdot 10^{-5}(205)$ & $2.8 \cdot 10^{-6}(231)$ & $3.2 \cdot 10^{-6}$ \\
$63<Z<74$ & $4.6 \cdot 10^{-5}(305)$ & $8.7 \cdot 10^{-6}(572)$ & $2.0 \cdot 10^{-6}$ \\
$75<Z<83$ & $5.0 \cdot 10^{-6}(33)$ & $4.6 \cdot 10^{-6}(292)$ & $8.7 \cdot 10^{-6}$ \\
$90<Z<96$ & $7 \cdot 10^{-7}(4)$ & $9.7 \cdot 10^{-7}(64)$ & $1.0 \cdot 10^{-7}$ \\
\hline
\end{tabular}

${ }^{(*)}$ Intervals for $Z$ are indicated as correspond to data of [15]

${ }^{(* *)}$ In parenthesis the number of registered tracks are indicated.

Practically, there are a number of computer programs for calculation of heavy ion stopping power in matter. In this paper, there are presented results of calculations for heavy ion ionization energy loss in olivine performed by SRIM2006 and GEANT4 programs. SRIM (Stopping and Range of Ions in Matter) [11] is a set of programs for fast table complication for stopping power, path and some other parameter values for any ions in wide energy interval. The calculations can be held for simple or compound target materials. The framework offered by GEANT4 $[12,13]$ object-oriented tool includes the simulation of high energy particle passage through the matter. This simulation tool was designed in CERN (European Organization for Nuclear Research, Geneva, Switzerland) for high energy physics experiments, but further found its application also in physical and technical areas, such as astronomy and others. The detector response package GEANT4 provides excellent capabilities for simulation of physical processes initiated by a high energy particle in detector models of different complexity. GEANT4 is a system with open code that helps users to understand what physical models are applied for event reconstruction and to get stared with the simulation tool.

In energy loss accompanying fast ion passing through the matter the process of target atoms ionization dominates (electron stopping power Se). The energy lost by proton with the same velocity $S_{\text {ei }}(T)=Z_{\text {eff }} S_{\text {ep }}\left(T_{p}\right)$, where $T$ - ion kinetic energy, $Z_{\text {eff }}$ - ion effective charge, $S_{\text {ep }}$ - stopping power of proton with velocity corresponding to kinetic energy $T_{p}=T M_{p} / M_{i}$, where $M_{p}, M_{i}$ are proton and ion masses respectively. Effective charge of fast ions $\left(T>10 Z_{i} M_{i} \mathrm{MeV} /\right.$ a.m.u.) equals $Z_{i}$. Low energy ions actively capture medium electrons and, consequently, have the mean charge $Z_{\mathrm{av}}=q Z_{i}$. For heavy ions, the average charge value differs from the effective one because the spatially distributed electrons of the moving heavy ion have an effect on its stopping power which differs from stopping power of the point charge. Parameter of the expression for ion mean charge is evaluated as

$$
q=1-\exp \left(0.803 y^{0.3}-1.3167 y^{0.6}-0.38157 y-0.008983 y^{2}\right),
$$

where $y=\frac{v_{i}}{v_{0} Z^{2 / 3}}\left(1+\frac{v_{F}^{2}}{5 v_{i}^{2}}\right), v_{F}-$ Fermi velocity of electrons in target material. 


\section{RESULTS OF CALCULATION}

We carried out the simulation of passing of $\mathrm{Xe}^{131}$ and $\mathrm{U}^{238}$ beams with energy $11.4 \mathrm{MeV} /$ nucleon through olivine with composition $\left(\mathrm{Mg}_{0.88} \mathrm{Fe}_{0.12}\right)_{2} \mathrm{SiO}_{4}$ characteristic for the Marjalahti pallasite. The latest version 4.8.2 of GEANT4 tool was used. On Fig. 2(a,b) there are given ionization energy loss plots for Xe ${ }^{131}$ and $\mathrm{U}^{238}$ in olivine in energy region where the energy loss exceeds the critical value $(d E / d x)_{c}$.

Moreover, by means of SRIM2006 and GEANT4 programs the energy losses of $\mathrm{Xe}^{131}$ and $\mathrm{U}^{238}$ ions in olivine $\left(\mathrm{Mg}_{0.88} \mathrm{Fe}_{0.12}\right)_{2} \mathrm{SiO}_{4}$ were calculated for a wide energy interval. In energy region $\sim 10 \mathrm{MeV} /$ nucleon a good agreement between two simulation scenarios is achieved. The estimation for ion path lengths got in GEANT4 simulation also agrees well with the same quantities obtained by SRIM2006.

We studied the experimental data of geometrical characteristics of tracks in olivine from the Marjalahti pallasite, exposed by V.P.Perelygin at 2000 on UNILAC accelerator in Durmstadt, Germany with Xe and U beams of the energy $11.4 \mathrm{MeV} /$ nucleon. Results of simulation were compared with available experimental data. On Fig. 3 the energy profile is presented, that is a point-by-point quantity of specific ionization energy loss along the trajectory for $\mathrm{Xe}^{131}$ and $\mathrm{U}^{238}$ passed through olivine with energy $11.4 \mathrm{MeV} /$ nucleon. The figure shows that the full path length of these particles in olivine is $(80-90) \mu \mathrm{m}$.

Results of the chemically etched track length calculation for some nuclei are presented in Table 1.

\section{EXPERIMENTAL RESULTS}

Obtained in our work up to this time experimental results of the galactic cosmic ray nuclei charge determination with $Z>55$ are presented in Table 2. For the nuclei charge identification the etching rate $\left(V_{\mathrm{TR}}\right)$ of the radiation-disordered zone in the olivine crystals along a trace of braking high-energy heavy nuclei was used. The great importance this parameter is especial gets at research of a charge spectrum of the nuclei with help of tracks, observed in the olivine crystals from the pallasites [14]. At the average size of crystals about 1 millimeter the majority of chemically etched sites of run of the nucleus traced in volume of each crystal, is submitted by tracks with the shortening registered length. In this connection the preliminary data of our studying, based on quantitative characteristics of the track etching velocity, gives on this stage of investigation some lowering nuclei charge values.

As a comparison of obtained in the present work data with the some other investigations, in Table 3 the results of the analogy track analyses, performed early in [15], just as an abundance of very heavy elements in the Solar system matter [16] are presented. Conclusion

Comparison of SRIM2006 and GEANT4 simulation results for accelerated nuclei $\mathrm{Xe}^{131}$ and $\mathrm{U}^{238}$ path lengths in olivine of the Marjalahti pallasite with the maximum values of etched track lengths shows close fit within experimental error limits. Thus, measurements of etched track full lengths in accordance with precisely measured track etching rate are of major importance for cosmic particle charge identification using the olivine crystals from meteorites.

This work is supported by RFBR grant № 06-02-16835.

1. Ginzburg V.L. // Usp. Fiz. Nauk. - 1999. - 169. - P.419.

2. Strutinsky V.M. // Nuclear Physics. - 1967. - A95. - P.420.

3. Oganesyan Yu.Ts. // Vestn. Ross. Akad. Nauk. - 2001. - 71. - P.590.

4. Perelygin V.P., Stetsenko S.G. // Pisma Zh. Exp. Teor. Fiz. - 1989. - 49. - P.257.

5. Ginzburg V.L., Feinberg E.L., Polukhina N.G., Starkov N.I., Tsarev V.A. // DAN. - 2005. - 402, № 4. - P. 1-3.

6. Fleischer R.L., Price P.B., Walker R.M., Maurette M. // J. Geophys. Res. - 1967. - 72. - P.331.

7. Aleksandrov A.B., Apacheva I.Yu., Feinberg E.L., Goncharova L.A., Konovalova N.S., Martynov A.G., Polukhina N.G., Rousettsskii A.S., Starkov N.I., Tsarev V.A. // Nucl. Instr. Methods Phys. Res. - 2004. - A535. - P.542.

8. Durrani C., Bull R. // Nuclear track detectors. - 1990.

9. Price P.B., Lal D., Tamhane A.S., Perelygin V.P. // Earth Planet. Sci. Lett. - 1973. - 19. - P. 377-395.

10. Horn P., et al. // Zeitschrift fur Naturforschung. - 1967. - 22a, № 11. - P. 1793-1798.

11. Ziegler J.F. The Stopping and Range of Ions in Matter. - SRIM-2006.

12. Allison J., et al. Geant4. Development and Applications // IEEE Transaction on Nuclear Science. - 53. P. 270-278.

13. Agostinelli S., et al. Geant4 A Simulation Toolkit // Nuclear Instrument and Methods. - 2003. - 506. P. 250-303.

14. Pellas P., Perron C. // Nuclear Instrument and Methods in Physics Research. - 1984. - B1. - P. 387-393.

15. Perelygin V.P., Otgonsuren O., Stetsenko S.G., Pellas P., Perron C. // Astrophys. J. - 1976. - 210. - P. 258-264.

16. Cameron A.G.W. // Space Ssi. Rev. - 1974. - 15. - P.121.

Received 24.10.2011 